\title{
Diets of Prairie Dogs, Goats, and Sheep on a Desert Rangeland
}

\author{
Miguel Mellado, ${ }^{1}$ Abundio Olvera, ${ }^{2}$ \\ Adrián Quero, ${ }^{3}$ and Germán Mendoza ${ }^{3}$
}

Authors are ${ }^{1}$ Professor, Department of Nutrition and Feeds, UAAAN, Saltillo, Mexico; and ${ }^{2}$ Graduate student and ${ }^{3}$ Professors, Department of Animal Science, Colegio de Posgraduados, Montecillos, Mexico.

\begin{abstract}
Diets of prairie dogs, goats, and sheep were examined by microhistological fecal analysis during 4 periods of a year in a desert rangeland in northern Mexico. Prairie dogs selected more grasses (79\% across all seasons; $P<0.05)$ than goats and sheep during most of the year. Total grasses in goat diets were consistent $(20 \%)$ in all seasons, whereas this forage class was highest during winter $(72 \%)$ and lowest during summer $(62 \%)$ in sheep diets. The diet of goats was predominantly shrubs $(45 \%-62 \%)$ in all seasons, whereas sheep and prairie dogs ate little browse throughout the study. All 3 species preferred forbs, which contributed about one-third to the composition of the prairie dog (winter), goat (summer), and sheep (spring) diets. Acacia greggii Gray and Opuntia rastrera Weber were the most preferred species by goats, whereas prairie dogs and sheep showed particular preference for Buchloe dactyloides (Nutt.) Engelm. and Bouteloua gracilis (Willd. ex Kunth) Lag. ex Griffiths. During summer and spring, concentration of nitrogen in the feces of sheep was $36 \%$ and $17 \%$ higher $(P<0.05)$ than in the feces of goats. There was a high overlap in diets between prairie dog and sheep in all seasons, whereas diets of prairie dogs and goats, and goats and sheep were significantly different from each other in all seasons. These results showed that competition was keen between prairie dogs and sheep for a limited quantity of forage in this arid zone pasture, whereas goats were better able to use common resources with prairie dogs.
\end{abstract}

\section{Resumen}

Se determinó la composición botánica de la dieta del perro de la pradera, cabras y ovejas utilizando la técnica microhistológica, durante cuatro periodos en un año en un pastizal desértico mediano abierto en el norte de México. Durante la mayor parte del año, los perros de la pradera seleccionaron una mayor cantidad de pastos (un 79\% de promedio a través del todas las estaciones año; $P<0.05)$ que las cabras y ovejas. El total de pastos en la dieta de las cabras fue consistente $(20 \%)$ en todas las estaciones, mientras que en la dieta de las ovejas esta clase de forraje alcanzó su máximo nivel en el invierno (72\%) y su nivel más bajo en el verano $(62 \%)$. Las arbustivas predominaron $(45 \%-62 \%$ del total del forraje utilizado) en la dieta de las cabras en todas las estaciones del año, mientras que las ovejas y perro de la pradera prácticamente ignoraron esta clase de forraje. Las 3 especies de animales mostraron una alta preferencia por las herbáceas, constituyendo éstas un tercio de la dieta de los perros de la pradera (invierno), cabras (verano) y ovejas (primavera). Acacia greggii y Opuntia rastrera fueron las especies más apetecidas por las cabras, en tanto que los perros de la pradera y ovejas mostraron una preferencia particular por Buchloe dactyloides y Bouteloua gracilis. Durante el verano y la primavera la concentración de nitrógeno en las heces de las ovejas fue $36 \%$ y $17 \%$ más alto $(P<0.05)$ que en las heces de las cabras. Se observó un marcado traslape en las dietas de los perros de la pradera y las ovejas durante las cuatro estaciones. Por otro lado, las dietas de los perros de la pradera y cabras y ovejas y cabras fueron significativamente diferentes en todas las estaciones del año. Estos resultados muestran que existió una aguda competencia entre los perros de la pradera y las ovejas por los escasos recursos forrajeros de este agostadero, mientras que las cabras mostraron una baja competencia por el alimento con los perros de la pradera por lo que tienen una mejor capacidad de usar en forma común estos recursos con los perros de la pradera.

Key Words: microhistological analysis, diet overlap, food selection, small ruminants

\section{INTRODUCTION}

In the arid zones of northern Mexico, sheep and goat production occurs primarily on rangelands. These small ruminants are managed under extensive systems in communal grazing land with high stocking rates. In some areas, small ruminants share rangeland resources with prairie dogs (Cynomix mex-

Correspondence: Miguel Mellado, UAAAN, Dept Nutrición y Alimentos, Saltillo, Coah. 25315, México. Email: mmellbosq@yahoo.com

Manuscript received 9 April 2004; manuscript accepted 27 February 2005. icanus), creating a potential competition among these animal species.

In arid ecosystems there are indications that, compared with sheep, non-Angora goats consume higher quantities of lignified species and select a wider variety of plants (Wilson et al. 1975; Warren et al. 1984a). Goats also have the ability to shift their diet from shrubs to forbs (Mellado et al. 1991, 2003) and are adapted to graze over rough terrain. As a result of different foraging styles, reach, use of front legs to access browse, and prehensile capabilities, diets of goats and sheep are often different (Warren et al. 1984a). On the other hand, on rangelands, grasses compose most of the diet of sheep (Bryant et al. 
1979; Ralphs et al. 1986) and black-tailed prairie dogs (Summers and Linder 1978; Fagerstone et al. 1981; Uresk 1984). Therefore diets selection is likely to overlap considerably between these herbivores. There is a question, however, as to what extent the diets of goats, sheep, and prairie dogs overlap on degraded grasslands in northern Mexico. Better information on the foraging ecology and dietary interrelationships among sheep, goats, and prairie dogs occupying the same rangeland would permit the design of better, more sustainable grazing programs. This study investigates the degree of similarity, overlap, and seasonal variation in the diets of goats, sheep, and prairie dogs in a Chihuahuan desert range in relation to forage availability.

\section{METHODS}

\section{Study Site}

The study was conducted during 2003 on 500 ha of range in northeastern Mexico (lat $26^{\circ} 26^{\prime} \mathrm{N}$, long $101^{\circ} 6^{\prime} \mathrm{W}$ ). The area comprises a valley and a low hill between 2050 and $2100 \mathrm{~m}$ altitude. Average annual precipitation is $307 \mathrm{~mm}$, with about $75 \%$ received from June to October (García and López 1997). Mean annual temperature is $13.4^{\circ} \mathrm{C}$. Soils of the study site are mainly well-drained alluvial soils (García and López 1997).

Sheep, goats, and prairie dogs grazed in common on a mixedgrass community comprising primarily Aristida arizonica Vasey, Buchloe dacyloides (Nutt.) Engelm., Stipa clandestina Hack., Erioneurum avenaceum (Kunth) Tateoka, Bouteloua uniflora Vasey, Bouteloua curtipendula (Michx.) Torr., and Bouteloua gracilis (Willd. ex Kunth) Lag. ex Griffiths. Major browse species were Flourensia cernua DC. and Quercus pringlei Seemen. Primary forb species include Tiquilia canescens (DC.) Richardson, Croton dioicus Cav., Zinnia acerosa (DC.) Gray, Solanum elaeagnifolium Cav., and Sphaeralcea angustifolia (Cav.) D. Don. The rangeland had been grazed at high intensity by goats and prairie dogs for several decades, which has changed the vegetation from a grass-dominated community to an herb-dominated pasture with poor forage productivity.

\section{Livestock Management}

A commercial flock of approximately 200 goats $(38-45 \mathrm{~kg}$ adult live weight) and 5 adult ewes (40-48 kg adult live weight) of undefined genotype was used. For several decades, heavy and continuous grazing was practiced extensively in a pasture of approximately 1500 ha with a single permanent water point. Animals were always herded by a shepherd and were returned to home corral every evening where they were kept overnight without water and feed. From these animals, 10 multiparous does and 5 adult ewes were used for fecal collection during the study. Adult goats used for fecal collection were similar in weight and phenotype (predominance of Nubian). For both goats and sheep, the breeding season occurred in February, with parturitions in June. Goats were hand-milked once a day during summer and fall. Water was available only once a day, and no mineral supplements were given during the study. The study site has large active prairie dog colonies, which are at least 50 years old. Number of burrows per hectare ranges from 62 to 100 , with an estimated population of 308 prairie dogs per hectare.

\section{Sampling Procedure}

Vegetation sampling was conducted before the start of fecal collections for each of the 4 seasonal periods, beginning in winter of 2002. Standing crop was determined by clipping individual plant species to ground level within 25 plots $(1 \times 1$ $\mathrm{m})$ scattered throughout the pasture (different plots on each sampling date). Because goats and sheep in this type of vegetation normally do not use shrub twigs, browse biomass was estimated considering only the foliage of these plants. Clipped samples were oven dried at $60^{\circ} \mathrm{C}$ for 48 hours then weighed to estimate air-dried standing crop.

There were 4 periods of fecal sampling: mid-January (winter), mid-April (spring), mid-July (summer), and mid-November (fall). In each sampling period, approximately 10 fecal pellets from each of 10 goats and 5 ewes were collected from the rectum during 5 consecutive days. Each sampling day, the fecal samples were separated into 2 subsamples; 1 was used for botanical and 1 for chemical analysis. The same ewes and goats were used for sampling throughout the experiment. In the case of prairie dogs, fresh fecal samples were collected in the proximity of 10 different burrows scattered on the entire pasture in which sheep and goats grazed throughout the year. The subsamples for botanical analysis were composited by animals across days within each collection period.

\section{Laboratory Methods}

Fecal samples were dried at $60^{\circ} \mathrm{C}$ for 48 hours and ground in a micro-Willey mill with a $1-\mathrm{mm}$ screen. Collections from each day made up 1 composite sample, for a total of 10 composite samples for each animal species and season. Two tablespoons of ground samples were soaked in hot water for 10 minutes to soften cell tissues and drained and rinsed in a 200 mesh tyler standard screen. Next, pigments were removed with chlorine bleach ( 5 minutes soaking). Samples were then spread on microscopic slides and mounted with Hoyer solution (Holechek 1982). Five slides were prepared from each composed sample, and 40 microscopic fields per slide were systematically viewed under $\times 100$ magnification. Epidermal fragments were identified to species level with fecal microhistological procedures (Sparks and Malechek 1968). Test slides were prepared for all plant species present in the grazing area to properly and consistently identify plant fragments. The Kjeldahl method was used to determine nitrogen content of feces (AOAC 1984). Phosphorus was determined by the method of Fiske and Subbarow (1925).

\section{Data Analysis}

Diet botanical composition was analyzed by analysis of variance in a split plot design (SAS Institute 1989). Animal species (3) were main plots and periods (4) were subplots. There was a significant interaction between seasons and animals for the major forage species in prairie dog, goat, and sheep diets. Therefore the model was reduced, and the data were analyzed separately to evaluate differences between animal species within seasons. Error terms for species of animals were the variation among animals within season. Each main plant species was analyzed separately. Least significant difference tests were used for mean separation when a significant $(P<0.05) F$ test occurred between animal species. Residuals from analysis of 


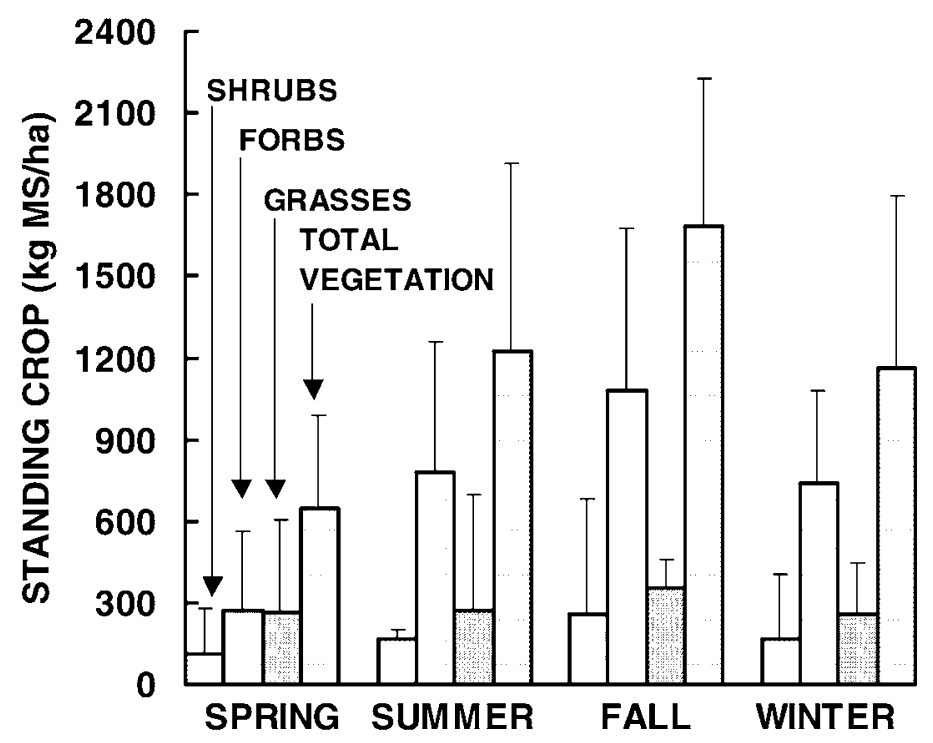

Figure 1. Standing crop of forage available during 4 sampling periods. Vertical bars are standard deviations of the means.

variance were normally distributed. Data were arcsine-transformed before analysis to satisfy assumptions of normality of variances.

Dietary overlap was determined with the proportional similarity index (PSI; Feinsinger et al. 1981):

$$
\text { PSI }=1-0.5 \sum\left(\left|\mathrm{P}_{\mathrm{i}}-\mathrm{Q}_{\mathrm{i}}\right|\right)
$$

where $\mathrm{P}_{i}$ is the proportion of species $i$ in the diet of animal $\mathrm{P}$, and $\mathrm{Q}_{i}$ is the proportion of species $i$ in the diet of animal $\mathrm{Q}$. The nonparametric Mantel test (Mantel 1967) was used to compare dietary overlap between prairie dogs and goats, prairie dogs and sheep, and goats and sheep.

A diet selectivity index was calculated for each plant present in feces as the ratio of each plant percentage in the diet to its percent availability in the rangeland (Plumb and Dodd 1993). An index value approaching 1.0 indicated nonselective use of a plant; values $>1.0$ or $<1.0$ indicated grazing selectivity for or against a particular plant, respectively. Selectivity was tested by calculating a $95 \%$ confidence interval for each mean selectivity value according to the procedure of Hobbs and Bowden (1982). Selectivity was significant if the interval did not contain the value 1.0 .

Because of the differences in digestive physiology of small ruminants and prairie dogs, fecal nitrogen and phosphorus were only compared between goats and sheep. These data were analyzed in a repeated measures design (SAS Institute 1989) with animal species and seasons as main effects.

\section{RESULTS}

\section{Forage Availability}

A total of 67 plant species was identified on the study area. Mean standing crop of forage during the rainy season (summer and fall) was almost double the standing crop during the dry season (spring; Fig. 1). On average, forbs accounted for about $60 \%$ of the forage available throughout the year. Proportion of biomass
Table 1. Mean seasonal diets (\%) of prairie dogs (PD), goats (G), and sheep (S) grazing in a Chihuahuan desert grassland in northern Mexico. ${ }^{1}$

\begin{tabular}{|c|c|c|c|c|c|c|c|c|c|c|c|c|}
\hline \multirow[b]{2}{*}{ Species $^{2}$} & \multicolumn{3}{|c|}{ Spring } & \multicolumn{3}{|c|}{ Summer } & \multicolumn{3}{|c|}{ Fall } & \multicolumn{3}{|c|}{ Winter } \\
\hline & PD & G & S & PD & G & S & PD & G & S & PD & G & S \\
\hline \multicolumn{13}{|l|}{ Shrubs } \\
\hline Agave lechuguilla & - & 3 & - & - & 3 & - & - & 2 & - & - & 4 & - \\
\hline Dalea bicolor & - & 4 & - & - & 4 & 2 & - & 4 & - & - & 3 & 4 \\
\hline Mimosa biuncifera & - & 4 & - & - & 3 & - & - & 3 & - & - & 5 & 2 \\
\hline Opuntia rastrera & 1 & 3 & - & $\mathrm{T}$ & 1 & - & - & 3 & - & - & $\mathrm{T}$ & - \\
\hline Quercus pringlei & - & 4 & 1 & - & 6 & - & - & 4 & - & - & 5 & 2 \\
\hline Other Shrubs & - & 18 & - & - & 34 & 5 & - & 42 & - & - & 27 & 1 \\
\hline Total Shrubs & $1^{\mathrm{a}}$ & $62^{b}$ & $1^{\mathrm{a}}$ & $\mathrm{T}^{\mathrm{a}}$ & $51^{b}$ & $7^{\mathrm{a}}$ & - & $58^{\mathrm{a}}$ & $1^{b}$ & - & $45^{\mathrm{a}}$ & $9^{b}$ \\
\hline \multicolumn{13}{|l|}{ Forbs } \\
\hline Croton dioicus & 1 & 3 & - & 2 & - & $\mathrm{T}$ & $\mathrm{T}^{\mathrm{a}}$ & $7^{\mathrm{b}}$ & $9^{b}$ & $2^{\mathrm{a}}$ & $5^{b}$ & $2^{\mathrm{a}}$ \\
\hline Sida abutifolia & - & 3 & 5 & - & 3 & 5 & $\mathrm{~T}^{\mathrm{a}}$ & $2^{\mathrm{a}}$ & $5^{b}$ & $4^{a}$ & $7^{\mathrm{b}}$ & $4^{a}$ \\
\hline Solanum & & & & & & & & & & & & \\
\hline elaeagnifolium & $5^{\mathrm{a}}$ & $6^{\mathrm{a}}$ & $4^{\mathrm{a}}$ & $4^{\mathrm{a}}$ & $7^{\mathrm{a}}$ & $4^{\mathrm{a}}$ & $2^{a}$ & $4^{\mathrm{a}}$ & $1^{\mathrm{a}}$ & $2^{\mathrm{a}}$ & $8^{\mathrm{b}}$ & $8^{b}$ \\
\hline Sphaeralcea & & & & & & & & & & & & \\
\hline angustifolia & $8^{a}$ & $4^{b}$ & $9^{a}$ & $4^{\mathrm{a}}$ & $8^{b}$ & $7^{\mathrm{ab}}$ & $3^{a}$ & $4^{a}$ & $6^{\mathrm{a}}$ & $7^{\mathrm{a}}$ & $5^{a}$ & $1^{\mathrm{b}}$ \\
\hline Other Forbs & 3 & 3 & 14 & 8 & 13 & 12 & 5 & 7 & 7 & 22 & 8 & 4 \\
\hline Total Forbs & $18^{\mathrm{a}}$ & $19^{\mathrm{a}}$ & $32^{b}$ & $18^{\mathrm{a}}$ & $31^{b}$ & $29^{b}$ & $11^{\mathrm{a}}$ & $24^{b}$ & $28^{b}$ & $37^{\mathrm{a}}$ & $33^{a}$ & $19^{b}$ \\
\hline
\end{tabular}

Grasses

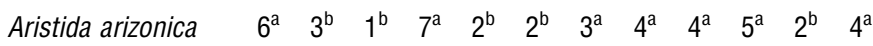
$\begin{array}{lllllllllllll}\text { A. curvifolia } & 4^{\mathrm{a}} & 2^{\mathrm{a}} & 6^{\mathrm{b}} & 6^{\mathrm{a}} & 2^{\mathrm{b}} & 4^{\mathrm{a}} & 6^{\mathrm{a}} & 2^{\mathrm{b}} & 6^{\mathrm{a}} & 7^{\mathrm{a}} & 2^{\mathrm{b}} & 8^{\mathrm{a}}\end{array}$

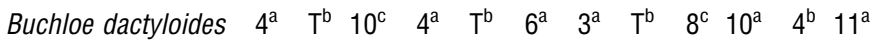
Bouteloua

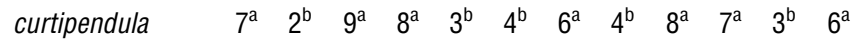

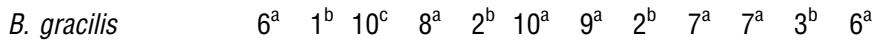

Erioneurum

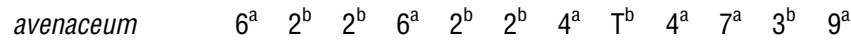

Muhlenbergia

$\begin{array}{lllllllllllll}\text { arenicola } & 4 & \mathrm{~T} & 0 & 5^{\mathrm{a}} & 1^{\mathrm{b}} & 1^{\mathrm{b}} & 9^{\mathrm{a}} & 2^{\mathrm{b}} & 6^{\mathrm{b}} & 6^{\mathrm{a}} & \mathrm{T}^{\mathrm{b}} & 4^{\mathrm{a}}\end{array}$

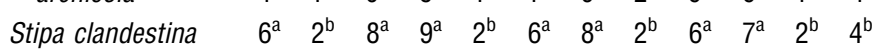

$\begin{array}{lllllllllllll}\text { Other Grasses } & 38 & 7 & 22 & 29 & 4 & 27 & 41 & 2 & 21 & 8 & 20 & 20\end{array}$

Total Grasses $\quad 81^{\mathrm{a}} \quad 20^{\mathrm{b}} \quad 68^{\mathrm{c}} \quad 82^{\mathrm{a}} \quad 19^{\mathrm{b}} \quad 62^{\mathrm{c}} \quad 89^{\mathrm{a}} \quad 19^{\mathrm{b}} \quad 70^{\mathrm{c}} \quad 64^{\mathrm{a}} \quad 22^{\mathrm{b}} \quad 72^{\mathrm{a}}$

${ }^{1}$ Empty cells indicate that plants were not used by animals. Values on the same line within season with different superscripts differ significantly $(P<0.05)$. T indicates trace $(<1 \%)$.

${ }^{2}$ Only main species are included.

composed of shrubs remained relatively constant throughout the year $(14 \%-17 \%$ of total forage), whereas yields of grass biomass composed a low proportion of this biomass $(22 \%$ of the total dry matter in summer, fall, and winter and $41 \%$ in spring). Overall, total forage declined from $1222 \mathrm{~kg} / \mathrm{ha}$ in summer to $645 \mathrm{~kg} / \mathrm{ha}$ in spring. In terms of biomass of forage classes, forbs were the dominant source of available forage in all seasons. Patchiness of the vegetation is indicated by the large standard deviations of the seasonal measures of forage availability.

\section{Diet Botanical Composition}

Throughout the study, 37 plant species were used by prairie dogs, 61 by goats, and 31 by sheep. Shrubs dominated the diet of goats throughout the year (Table 1). Four shrubs, Agave lechuguilla Torr., Dalea bicolor (Gray) H.\&B., Mimosa biuncifera Benth., and Q. pringlei made up about $15 \%$ of the goat 
Table 2. Mean $\pm S D$ fecal nitrogen and phosphorus concentration (percentage of dry matter) for goats and sheep for 4 seasons on desert rangeland in poor condition.

\begin{tabular}{lccc}
\hline Season & Species & Fecal N $^{1,2}$ & Fecal $P^{1,2}$ \\
\hline Spring & Goat & $1.4 \pm 0.4^{\mathrm{a}}$ & $1.9 \pm 0.1^{\mathrm{a}}$ \\
& Sheep & $1.9 \pm 0.1^{\mathrm{b}}$ & $2.1 \pm 0.3^{\mathrm{a}}$ \\
& Mean & $1.7 \pm 0.4^{\mathrm{A}}$ & $2.0 \pm 0.2^{\mathrm{A}}$ \\
Summer & Goat & $2.3 \pm 0.3^{\mathrm{a}}$ & $1.2 \pm 0.2^{\mathrm{a}}$ \\
& Sheep & $2.7 \pm 0.1^{\mathrm{b}}$ & $1.2 \pm 0.2^{\mathrm{a}}$ \\
& Mean & $2.5 \pm 0.3^{\mathrm{B}}$ & $1.2 \pm 0.2^{\mathrm{B}}$ \\
Fall & Goat & $2.0 \pm 0.1^{\mathrm{a}}$ & $0.7 \pm 0.1^{\mathrm{a}}$ \\
& Sheep & $1.9 \pm 0.1^{\mathrm{a}}$ & $0.8 \pm 0.2^{\mathrm{a}}$ \\
& Mean & $2.0 \pm 0.1^{\mathrm{C}}$ & $0.8 \pm 0.1^{\mathrm{C}}$ \\
Winter & Goat & $1.9 \pm 0.2^{\mathrm{a}}$ & $1.9 \pm 0.2^{\mathrm{a}}$ \\
& Sheep & $2.1 \pm 0.4^{\mathrm{a}}$ & $2.1 \pm 2.1^{\mathrm{a}}$ \\
& Mean & $2.0 \pm 0.3^{\mathrm{C}}$ & $1.1 \pm 0.2^{\mathrm{B}}$ \\
\hline
\end{tabular}

${ }^{1}$ Means for kind of animal within columns and seasons with different lowercase letters are significantly different $(P<0.05)$

${ }^{2}$ Means for seasons within columns with different capital letters are significantly different $(P<0.01)$

diet in all seasons, and total shrub utilization by goats was several times greater $(P<0.05)$ than that of prairie dogs and sheep. Shrubs contributed $<1 \%$ to prairie dog diets throughout the study. Opuntia rastrea was the only shrub eaten (trace amounts) in spring and summer by prairie dogs. Shrubs were scarce in sheep diets, and they reached a maximum of $9 \%$ in winter. $D$. bicolor was the only shrub eaten by sheep in significant amounts after the rainy season. In contrast to prairie dogs and goats, sheep avoided Opuntia spp.

Forbs composed one-third of the goat (summer and winter), sheep (spring), and prairie dog (winter) diets. During the dry season (winter and spring), forbs were used in equal proportion by prairie dogs and goats, but during the rainy season (summer and fall), the proportion of forbs was 2 -fold greater $(P<0.05)$ in goat diets than in prairie dog diets. During summer and fall, equal proportions of forbs occurred in the diets of goats and sheep, but in spring, sheep consumed more $(P<0.05)$ forbs than goats and prairie dogs. Only 2 forbs were consistently used by prairie dogs, goats, and sheep throughout the year: $S$. elaeagnifolium and $S$. angustifolia. These plants were the most important components of the goat's diet for most of the year. C. dioicus was the most important component of the goat and sheep diets in the fall, when the contribution of this plant to goat and sheep diets was several times greater $(P<0.05)$ than in the diet of prairie dogs.

Prairie dogs and sheep relied heavily on grasses throughout the study, whereas this forage class contributed $<22 \%$ to goat diets. During spring, summer, and fall, grasses contributed $>81 \%$ of the prairie dog diet. This level of grass use was greater $(P<0.05)$ than that of goats and sheep. Sheep use of $B$. dactyloides and B. gracilis showed the lowest seasonal variation of all grasses and were the most important components of the sheep's diet. Equal proportions of B. dactyloides occurred in the diets of prairie dogs and sheep in summer and winter, but for the rest of the study, sheep used more $(P<0.05)$ $B$. dactyloides than prairie dogs. For most of the study, $B$. curtipendula and B. gracilis were found in equal amounts in
Table 3. Selectivity index for main species used by prairie dogs (PD), goats $(G)$, and sheep $(S)$ in a desert rangeland over 1 year. ${ }^{1}$

\begin{tabular}{|c|c|c|c|c|c|c|c|c|c|c|c|c|}
\hline \multirow[b]{2}{*}{ Species } & \multicolumn{3}{|c|}{ Spring } & \multicolumn{3}{|c|}{ Summer } & \multicolumn{3}{|c|}{ Fall } & \multicolumn{3}{|c|}{ Winter } \\
\hline & PD & G & $S$ & PD & G & $S$ & PD & G & S & PD & G & $S$ \\
\hline Acacia greggii & - & 4.0 * & - & - & 1.2 & - & - & 1.3 & - & - & 4.0 & - \\
\hline Agave lechuguilla & - & 0.6 & - & - & 1.0 & 1.0 & - & 1.0 & - & - & -1.3 & - \\
\hline Dalea bicolor & - & 2.0 & - & - & 2.0 & - & - & 2.0 & - & - & 1.5 & - \\
\hline Mimosa biuncifera & $a-$ & 1.0 & - & - & 0.6 & - & - & 0.6 & - & - & 0.2 & - \\
\hline Quercus pringlei & - & 1.3 & 0.3 & - & 1.5 & - & - & 1.3 & - & - & 1.7 & - \\
\hline Opuntia rastrera & 0.5 & 1.5 & - & 0.8 & 1.0 & - & - & $3.0 *$ & * - & - & 0.7 & - \\
\hline Crorton dioicus & 0.3 & 2.0 & - & 1.2 & - & 0.8 & 0.3 & $2.3^{*}$ & * 3.0 * & * 1.0 & 2.5 & 1.0 \\
\hline Sida abutifolia & - & 1.5 & 2.5 & 一 & - & - & 0.4 & 1.0 & 2.5 & 2.0 & $3.5^{*}$ & * 2.0 \\
\hline \multicolumn{13}{|l|}{ Solanum } \\
\hline elaeagnifolium & 1.3 & 1.5 & 1.0 & 1.0 & 1.8 & 1.0 & 1.0 & 2.0 & 0.5 & 0.7 & 2.7 * & * $2.7 *$ \\
\hline \multicolumn{13}{|l|}{ Sphaeralcea } \\
\hline angustifolia & $2.7^{*}$ & +1.3 & 3.0 & 1.0 & $2.0 *$ & * $1.8 *$ & $k 1.0$ & 2.0 & 1.3 & 2.3 & 1.7 & 0.3 \\
\hline Aristida arizonica & 2.0 & 1.0 & 0.3 & 1.2 & 0.3 & 0.3 & 1.5 & 1.5 & 2.0 & 1.7 & 0.7 & 1.3 \\
\hline A. curvifolia & 2.0 & 2.0 & 3.0 & 1.5 & 0.5 & 1.0 & 0.9 & 0.3 & 0.9 & 1.0 & 0.3 & 1.2 \\
\hline \multicolumn{13}{|l|}{ Buchloe } \\
\hline dactyloides & 1.3 & $0.2^{\star}$ & $3.3 *$ & 2.0 & 0.4 & 3.0 & 1.0 & $0.2^{\star}$ & * 2.7 * & * 3.3 * & * 1.3 & $3.7^{*}$ \\
\hline \multicolumn{13}{|l|}{ Bouteloua } \\
\hline curtipendula & $2.3^{*}$ & 0.7 & 3.0 & 1.0 & 0.4 & 0.5 & 2.0 & 1.3 & $2.7^{\star}$ & * 2.3 & 1.0 & 2.0 \\
\hline B. gracilis & 1.5 & 0.3 & 2.5 & 4.0 * & * 1.0 & $5.0 *$ & +1.5 & 0.3 & 1.2 & $3.5^{\star}$ & * 1.5 & $4.5^{\star}$ \\
\hline \multicolumn{13}{|l|}{ Erioneurum } \\
\hline avenaceum & 1.0 & 0.3 & 0.3 & $3.0 *$ & $* 1.0$ & 1.0 & 2.0 & 0.4 & 2.0 & 2.0 & 0.9 & $3.0^{*}$ \\
\hline \multicolumn{13}{|l|}{ Muhlenbergia } \\
\hline arenicola & 1.5 & 0.4 & - & 2.5 & 0.3 & 0.5 & $3.0 *$ & * 0.4 & 1.0 & 3.0 & 0.4 & 2.0 \\
\hline Stipa clandestina & 2.0 & 0.5 & 2.0 & 1.5 & 0.5 & 1.0 & 1.5 & 0.3 & 1.0 & 1.8 & 0.4 & 0.8 \\
\hline
\end{tabular}

${ }^{1}$ Empty cells indicate that plants were not used by animals. Values with asterisks indicate that $95 \%$ Cls for seasonal diets do not contain the value 1

prairie dog and sheep diets. During spring and summer, the use of E. avenaceum by prairie dogs was 3 -fold greater $(P<0.05)$ than sheep. During most of the study, prairie dogs consumed more $(P<0.05)$ Mublenbergia arenicola Buckl. than sheep and goats.

\section{Fecal Nitrogen and Phosphorus}

Animal species main effect was significant for fecal nitrogen but not for phosphorus concentration. A significant $(P=0.04)$ interaction occurred between animal species and season for fecal nitrogen. During summer and spring, concentration of nitrogen in the feces of sheep was $36 \%$ and $17 \%$ higher $(P<0.05)$ than in the feces of goats (Table 2). Season main effect was significant for both fecal nitrogen and phosphorus. The highest levels of nitrogen in the feces of these small ruminants were in summer, whereas the highest level of fecal phosphorus occurred in spring.

\section{Diet Preference and Overlap}

Only goats showed selection for some shrubs compared with their availability (Table 3). Acacia greggii in spring and $O$. rastrera in fall were the most preferred species by goats, although these species were not the principal components of the diet. Other shrubs, such as A. lechuguilla and M. biuncifera, were consumed either in equal proportion to or below their seasonal availability in the pasture. Goats and sheep showed 
a greater preference for the main forb species than prairie dogs did. Prairie dogs and sheep selected for grasses at all times of the year, showing particular preference for $B$. dactyloides and $B$. gracilis. Goats, on the other hand, in general consumed grasses in lower proportion than their seasonal availability and showed strong avoidance of $B$. dactyloides. There was a high overlap in diets between prairie dog and sheep in all seasons (Fig. 2). The Mantel test indicated that diets of prairie dog and goats, and goats and sheep were significantly different from each other in all seasons.

\section{DISCUSSION}

Goats ate a broad diet that was seasonally variable. During winter, goats shifted their diets, with a major decrease in shrubs and an increase in forbs. These changes appear to reflect the abundance of forbs during this season. Forbs do not persist through the cold and dry winter of this area, and even though forbs were dry and of low quality, they were readily eaten by goats. These data reaffirm the opportunistic foraging strategy of goats, which are capable of drastic shifts in their diets depending on forage availability and quality (Mellado et al. 1991; Ramirez et al. 1991; Papachristou and Nastis 1993; Mellado et al. 2003). Although shrubs were a minor component of the available forage $(14 \%-17 \%$ of the total forage available), they were the most important constituent of the goat diet throughout the year. Several studies in arid environments have reported that goats are eminently browsers (Sidahmed et al. 1981; Warren et al. 1984b; Mellado et al. 2003) because their diets contain $>50 \%$ browse. This study supports this view because goat consumption of shrubs averaged 54\% throughout the study. Q. pringle $i$ was the most abundant shrub in the goat diet. This short shrub is highly preferred by goats because of its substantial contribution of nutrients and absence of toxic effects (Villena and Pfister 1990). In this herbdominated plant community, both prairie dogs and sheep virtually ignored browse species; thus, the consumption of shrubs by goats did not result in an interspecific resource competition for this forage class. The only shrub used by prairie dogs (trace amounts) was O. rastrera. In other ecosystems with higher density of this Cactaceae, prairie dogs rely heavily on this forage (Summers and Linder 1978; Fagerstone et al. 1981).

Forbs were an important forage source for the 3 animal species (percent contribution of forbs to the diets of prairie dogs, goats, and sheep averaged across 4 seasons was $21 \%$, $29 \%$, and $27 \%$, respectively). The importance of herbs in the diets of these herbivores in arid and semiarid environments has been amply documented. In areas with scarce precipitation, actively growing forbs are less than one-third of the goat diet (Mellado et al. 1991; Fajemisin et al. 1996). The same is true for sheep (Kothmann 1968; Bryant et al. 1979), although on range in good condition, forbs can constitute $>50 \%$ of the sheep diet (Kothmann 1968; Ralphs et al. 1986). Prairie dogs in this study shifted their forb utilization as the season changed. When grasses were mature in winter, forbs began to replace the graminoid components of the diet. These observations are consistent with those of Uresk (1984), who observed an increase of forbs from $5 \%$ in summer to $25 \%$ in the fall. Other researches have reported much higher proportions of forbs $(73 \%)$ in the prairie dog diet (Fagerstone et al. 1977). Two

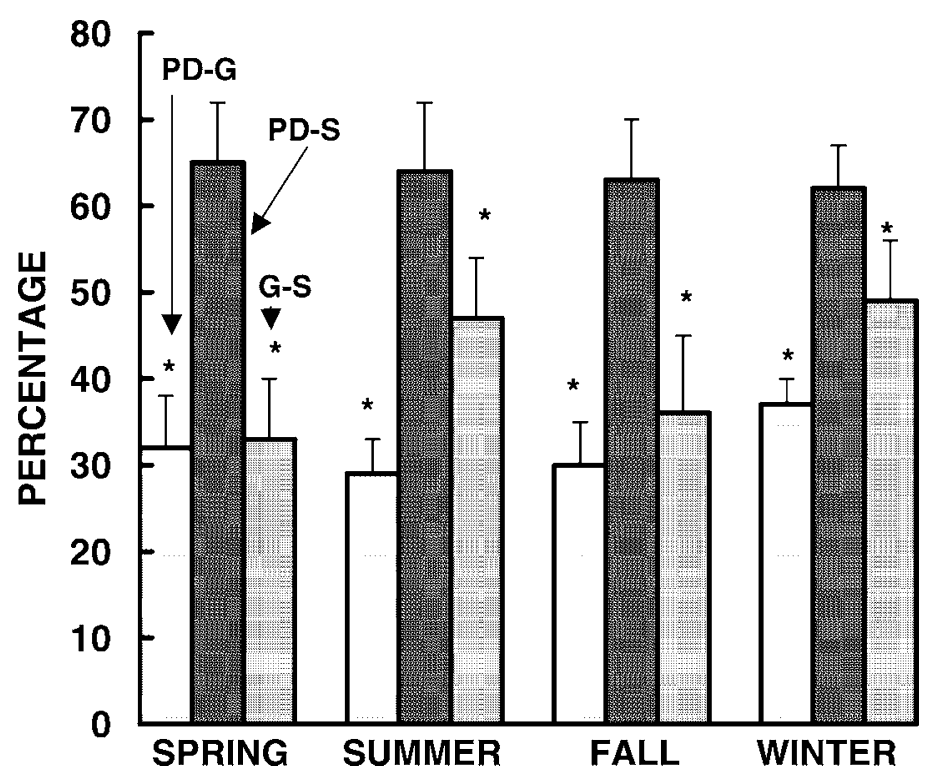

Figure 2. Dietary overlap between the 3 herbivores species during 4 sampling periods. Vertical bars are standard deviations of the means. PD-G indicates prairie dogs and goats; PD-S, prairie dogs and sheep; and G-S, goats and sheep. Columns are means + SE bar. * Species have significantly different diets $(P<0.05)$ by the Mantel test.

forbs of singular importance for the 3 animal species throughout the year were S. elaeagnifolium and S. angustifolia, which made up 9,12 and $10 \%$ of the prairie dog, goat and sheep diets, respectively (average across 4 seasons). The importance of these forage species for prairie dogs (Fagerstone et al. 1977; Summers and Linder 1978; Uresk 1984) and goats (Mellado et al. 2003, 2004) has been previously reported. The trends for forbs in diets of the 3 kinds of animals and standing crop suggest that competition was intense throughout the study period. Critical competition probably occurred in spring because forbs represented one-third of the sheep diet, and this forage class was at its lowest availability.

In general, all 3 species of animal were consistent in their use of grasses throughout the year. For prairie dogs and sheep, grasses provided the base for their diet in all seasons. Prairie dog and sheep preference for grasses was not coupled with the availability of this forage class. These findings support the contention that prairie dog diets are dominated by grass (Hansen and Gold 1977; Summers and Linder 1978; Uresk 1984). Sheep, on the other hand, exhibit considerable flexibility in selecting forage, with large variation in the percentage of grasses in their diets (Bryant et al. 1979; Ramirez et al. 1995; Kronberg and Malechek 1997; Brand 2000). Grass was the least prevalent of the 3 forage classes in the goat diets, and although graminoids constituted an important part of goat diets, goats continued to follow a browsing strategy. Grass use by goats in our study was several times larger than that reported in shrub-dominated plant communities in arid zones (Sidahmed et al. 1981; Mellado et al. 1991, 2003, 2004), which reaffirms that goats are very flexible in the vegetation classes they consume. By looking at the selectivity indices, it was clear that grasses were not preferred items for goats. B. dactyloides in particular was rejected by goats. Bartolomé et al. (1998) also found that sheep selected graminoids throughout the year 
whereas goats tended to avoid them. Prairie dogs showed a seasonal preference for $B$. dactyloides, B. curtipendula, $B$. gracilis, E. avenaceum, and $M$. arenicola, which suggests that the palatability of these species varied seasonally. Summers and Linder (1978) reported that some of these grasses were important forage plants for black-tailed prairie dogs in South Dakota. The same grasses, except $M$. arenicola, were highly preferred by sheep. $S$. clandestina, a grass not considered good forage for cattle because of its thick cell wall and marginal level of protein in certain periods of the year (Ganskopp 1998), was an important component of both prairie dog and sheep diets throughout the year, although its selectivity index was low, indicating that prairie dogs and sheep were not seeking out this grass.

Trends of percent grasses in the diets of the 3 kinds of animals were more similar between prairie dog and sheep, whereas trends for goat and prairie dog and goat and sheep were dissimilar. Thus, it appears that competition was keen between prairie dog and sheep for a limited quantity of grass (grasses accounted for only $25 \%$ of the standing crop). This competition could force prairie dogs to reduce drastically their use of grass in winter, shifting their preferences to forbs (dead plant tissue at this time of the year), which apparently were an important buffer against low grass supply during the dry period. It is worth mentioning that a high level of forage overlap does not necessarily mean that competition is occurring (Jenkins and Wright 1988) because it is the density of individuals relative to the resource base that determines the strength of competitive interactions. In this study, the standing crop was very low as a result of several decades of overgrazing; thus, sharing of common resources by sheep and prairie dogs could have resulted in competition.

Despite the potential confounding effects of tannins (presence of tannins elevate fecal nitrogen concentrations), fecal nitrogen is a useful method of monitoring dietary nitrogen in ruminants (Osborn and Ginnett 2001). Fecal indices such as nitrogen and phosphorus are strongly related to nutritional status in grazing ruminants (Holechek et al. 1982; Hakkila et al. 1988; Osborn and Jenks 1998; Blanchard et al. 2003). In this study, the higher fecal nitrogen of sheep compared with goats in spring and summer implied that sheep selected diets higher in crude protein than those chosen by goats during this period. These observations are consistent with those of Kronberg and Malechek (1997), who reported that sheep ingested a diet higher in protein than goats did. The large consumption of forbs in spring and the ingestion of large amounts of actively growing grasses in summer appear to explain the higher nitrogen in the feces of sheep compared with goats.

\section{MANAGEMENT IMPLICATIONS}

This study showed little difference in diet botanical composition between sheep and prairie dogs over a 1-year period in an herb-dominated plant community, which makes exploitative competition between these herbivores possible. On the other hand, the overlap in forage resource use between goats and prairie dogs and goats and sheep was generally low because of the broader dietary niche of goats in all seasons. Despite the more complex diet of goats, fecal nitrogen in these animals was lower than that of sheep during 2 seasons, which implies that goats chose their diet with less selectivity for crude protein than sheep.

Because goats readily ate a number of native shrubs present in the prairie dog colony and because these shrubs were not used by prairie dogs, there appears to be a high potential for grazing goats along with prairie dogs to more efficiently harvest the available forage resources. On the other hand, high densities of sheep in prairie dog colonies could have an important negative effect on the forage resources for prairie dogs because of the graminivorous feeding habits of both sheep and prairie dogs.

\section{LITERATURE CITED}

AOAC. 1984. Official methods of analysis. 14th ed. Washington, DC: Association of Official Analytical Chemists. p 14-15.

Bartolomé, J., J. Franch, J. Plaixats, and N. G. Seligman. 1998. Diet selection by sheep and goats on Mediterranean heath-woodland range. Journal of Range Management 51:383-391.

Blanchard, P., M. Festa-Bianchet, J. M. Gaillard, and J. T. Jorgenson. 2003. A test of long-term fecal nitrogen monitoring to evaluate nutritional status in bighorn sheep. Journal of Wildlife Management 76:477-484.

Brand, T. S. 2000. Grazing behaviour and diet selection by Dorper sheep. Small Ruminant Research 36:147-158.

Bryant, F. C., M. M. Kothmann, and L. B. Merril. 1979. Diets of sheep, Angora goats, Spanish goats, and white-tailed deer under excellent range conditions. Journal of Range Management 32:412-417.

Fagerstone, K. A., H. P. Tietuen, and G. K. Lavoie. 1977. Effects of range treatment with 2,4-D on prairie dog diets. Journal of Range Management 30:57-60.

Fagerstone, K. A., H. P. Tietuen, and 0. Williams. 1981. Seasonal variation in the diet of black-tailed prairie dogs. Journal of Mammalogy 62:820-824.

Fajemisin, B., D. Ganskopp, R. Cruz, and D. M. Vavra. 1996. Potential for woody plant control by Spanish goats in the sagebrush steppe. Small Ruminant Research 20:99-107.

Feinsinger, P., E. E. Spears, and R. W. Poole. 1981. A simple measure of niche breadth. Ecology 62:27-32.

FISKE, C. H., AND Y. SUBBAROW. 1925. The colorimetric determination of phosphorus. Journal of Biological Chemistry 66:371-375.

GanskoPP, D. 1998. Thurber needlegrass: seasonal defoliation effects on forage quantity and quality. Journal of Range Management 51:276-281.

García, R., and R. López. 1997. Rancho demostrativo "Los Angeles." Monografía histórica (1930-1995). Saltillo, Mexico: Bulletin University Autonoma Agraria Antonio Narro. $38 \mathrm{p}$.

Hakkila, J. L., J. D. Wallace, D. M. Anderson, and M. Cardenas. 1988. Fecal indicators of cattle protein status on desert grassland range. Nutrition Reproduction International 37:137-147.

Hansen, R. M., AND I. K. Gold. 1977. Blacktail prairie dogs, desert cottontail and cattle trophic relations on shortgrass range. Journal of Range Management 30:210-214.

HobBS, N. T., AND D. C. Bowden. 1982. Confidence intervals on food preferences indices. Journal of Wildlife Management 46:505-507.

HoLECHEK, J. L. 1982. Sample preparation technique for microhistological analysis. Journal of Range Management 35:267-268.

Holechek, J. L., M. Vavra, and D. Arthun. 1982. Relationships between performance intake, diet nutritive quality and fecal nutritive quality of cattle on mountain range. Journal of Range Management 35:741-744.

JenkINS, K. J., AND R. G. WRIGHT. 1988. Resource partitioning and competition among cervids in the northern Rocky Mountains. Journal of Applied Ecology 25:11-24.

Kothmann, M. M. 1968. The botanical composition and nutrient content of the diet of sheep grazing on poor condition pasture compared to good condition pastures [dissertation]. College Station, TX: Texas A\&M University.

Kronberg, S. L., and J. C. MaleCheK. 1997. Relationship between nutrition and foraging behavior of free-ranging sheep and goats. Journal of Animal Science 75:1756-1763. 
Mantel, N. 1967. The detection of disease clustering and a generalized regression approach. Cancer Research 27:209-220.

Mellado, M., R. H. Foote, A. Rodríguez, and P. Zarate. 1991. Botanical composition and nutrient content of diet selected by goat grazing on desert grassland in northern Mexico. Small Ruminant Research 6:141-150.

Mellado, M., A. Rodríguez, J. A. Villarreal, and R. Lopez. 2004. Age and body condition on diets of grazing goats. Journal of Range Management 57:517-523.

Mellado, M., R. Valdez, L. M. Lara, and R. Lopez. 2003. Stocking rate effects on goats: a research observation. Journal of Range Management 56:167-173.

Osborn, R. G., AND T. F. Ginnett. 2001. Fecal nitrogen and 2,6-diaminopimelic acid as indices to dietary nitrogen in white-tailed deer. Wildlife Society Bulletin 29:1131-1139.

Osborn, R. G., AND J. A. Jenks. 1998. Assessing dietary quality of white-tailed deer using fecal indices: effects of supplemental feeding and area. Journal of Mammalogy 79:437-447.

Papachristou, T. G., AND A. S. Nastis. 1993. Diets of goats grazing oak shrublands of varying cover in northern Greece. Journal of Range Management 46:420-426.

Plumb, G. E., AND J. L. DodD. 1993. Foraging ecology of bison and cattle on a mixed prairie. Ecological Applications 3:631-643.

Ralphs, M. H., M. M. Kothmann, and L. B. MerRil. 1986. Cattle and sheep diets under short-duration grazing. Journal of Range Management 39:217-223.

Ramirez, R. G., A. Loyo, R. Mora, E. M. Sanchez, and A. Chaire. 1991. Forage intake and nutrition of range goats in a shrubland in northeastern Mexico. Journal of Animal Science 69:879-885.

Ramirez, R. G., E. Mireles, J. M. Huerta, and J. Aranda. 1995. Forage selection by range sheep on a buffelgrass (Cenchrus ciliaris) pasture. Small Ruminant Research 17:129-135.

SAS InstituTE. 1989. SAS/Stat user's guide. Version 6. Cary, NC: SAS Institute Inc. p 236-237.

Sidahmed, A. E., J. G. Morris, and S. R. Radosevich. 1981. Summer diet of Spanish goats grazing chaparral. Journal of Range Management 34:33-35.

Sparks, D. R., AND J. C. MalecheK. 1968. Estimating percentage dry weight in diets using a microscope technique. Journal of Range Management 21:264-265.

Summers, C. A., AND R. L. LINDER. 1978. Food habits of the black-tailed prairie dog in western South Dakota. Journal of Range Management 31:134-136.

URESK, D. W. 1984. Black-tailed prairie dog food habitats and forage relationships in Western South Dakota. Journal of Range Management 37:325-329.

Villena, F., and J. A. Pfister. 1990. Sand shinnery oak as forage for Angora and Spanish goats. Journal of Range Management 43:116-122.

Warren, L. E., D. N. UeCKert, and J. M. Shelton. 1984a. Comparative diets of Rambouillet, Barbado, and Karakul sheep and Spanish and Angora goats. Journal of Range Management 37:172-180.

Warren, L. E., D. N. Ueckert, J. M. Shelton, and A. D. Chamrad. 1984b. Spanish goat diets on a mixed-brush rangeland in the south Texas plains. Journal of Range Management 37:340-342.

Wilson, A. D., J. H. Leigh, N. L. Hindley, and W. E. Mulham. 1975. Comparison of the diets of goats and sheep on a Casuarina cristata-Heterodendrum oleifolium woodland community in western New South Wales. Australian Journal of Experimental Agriculture and Animal Husbandry 15:45-53. 